\title{
BIOCHEMICAL AND HAEMATOLOGICAL VALUES IN VENOUS BLOOD OF CAPTIVE RED DEER (Cervus elaphus) AT HIGH ALTITUDE
}

\author{
S. PADILLA ${ }^{1}$, J. BOUDA ${ }^{1}$, G. F. QUIROZ-ROCHA ${ }^{1}$, J. L. DÁVALOS ${ }^{2}$, A. SÁNCHEZ ${ }^{2}$ \\ Department of Clinical Pathology ${ }^{1}$, Centre of Ruminant Production ${ }^{2}$, College of Veterinary Medicine, \\ National Autonomous University of Mexico, 04510 Mexico City, Mexico
}

Received June 6, 2000

Accepted November 22, 2000

\section{Abstract}

Padilla S., J. Bouda, G. F. Quiroz-Rocha, J. L. Dávalos, A. Sánchez: Biochemical and Haematological Values in Venous Blood of Captive Red Deer (Cervus elaphus) at High Altitude. Acta Vet. Brno 2000, 69: 327-331.

Biochemical values were determined in venous blood of 30 and haematological values in 60 red deer of average body mass $53.9 \mathrm{~kg}$, aged 5 months, kept on pasture in Central Mexico at the altitude of $2450 \mathrm{~m}$. In blood samples from jugular vein of clinically healthy animals without sedation, the average serum concentrations were as follows: urea $6.32 \mathrm{mmol} / \mathrm{L}$, glucose $5.09 \mathrm{mmol} / \mathrm{L}, \mathrm{Na}^{+} 142.3$ $\mathrm{mmol} / \mathrm{L}, \mathrm{K}^{+} 7.03 \mathrm{mmol} / \mathrm{L}, \mathrm{Cl}^{-} 100.5 \mathrm{mmol} / \mathrm{L}, \mathrm{Ca}^{2+} 2.12 \mathrm{mmol} / \mathrm{L}$, inorganic $\mathrm{P} 2.41 \mathrm{mmol} / \mathrm{L}^{2} \mathrm{Mg}^{2+}$ $0.91 \mathrm{mmol} / \mathrm{L}, \mathrm{Cu} 9.86 \mu \mathrm{mol} / \mathrm{L}, \mathrm{Zn} 16.97 \mu \mathrm{mol} / \mathrm{L}$ and activity of AST 54.3 IU/L and creatine kinase $221 \mathrm{IU} / \mathrm{L}$. Blood pH was 7.41, pCO $37.7 \mathrm{~mm} \mathrm{Hg}$, actual bicarbonate $24.3 \mathrm{mmol} / \mathrm{L}$, base excess $0.73 \mathrm{mmol} / \mathrm{L}$, total $\mathrm{CO}_{2} 25.3 \mathrm{mmol} / \mathrm{L}$, haemoglobin $156 \mathrm{~g} / \mathrm{L}, \mathrm{PCV} 0.47 \mathrm{~L} / \mathrm{L}$, leukocytes 4.8 x $10^{9} / \mathrm{L}$ and plasma protein $66.0 \mathrm{~g} / \mathrm{L}$. Biochemical and haematological values determined in red deer at the altitude above $2000 \mathrm{~m}$ are the first reference and can be used for health control and diagnosis of diseases.

Red deer, venous blood, biochemical values, haematology, high altitude

In recent years red deer has been farmed in Mexico. Some biochemical and haematological analytes have been described in this species, however, their values depend mainly on nutrition, management and environmental conditions. Biochemical and haematological values are important for monitoring of health status and diagnosis of diseases. Great differences were described in values of plasma analytes, especially in concentrations of $\mathrm{Na}^{+}$and $\mathrm{K}^{+}$in red deer (Wils on and Pauli 1983; Knox et al. 1988; Hargreaves and Matthews 1995).

The objective of this study was to determine biochemical and haematological values in venous blood of farm red deer in central Mexico at the altitude of $2450 \mathrm{~m}$.

\section{Materials and Methods}

Blood biochemical values were determined in 30 red deer (Cervus elaphus) (15 males, 15 females) and haematological values in 60 animals ( 30 males and 30 females) aged 5 months, average body mass $53.9 \mathrm{~kg}$ without clinical signs of disease. The animals were kept on pasture in the Valley of central Mexico at the altitude of 2450 $\mathrm{m}$. The climate was moderate, rainy during summer, with average temperature between 5 and $14{ }^{\circ} \mathrm{C}$. The pasture was composed of rye grass, orchard, kikuyo, white clover and alfalfa. Daily calculated dry matter consume was $2.06 \mathrm{~kg}$ per animal. During sampling the animals without sedation were gently restrained in standing position, in a small pen, with covered eyes and plugged ears.

Samples of blood were taken from jugular vein into plain tubes for biochemical analyses, into tubes containing

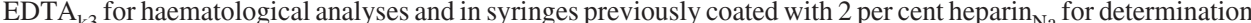
of acid-base values. The air bubbles were expelled from the syringe immediately after blood collection and then the needle was inserted into a rubber stopper to prevent exposure of sample to air. The sealed syringes after collection were immersed in a mixture of ice and water.

Address for correspondence:

J. Bouda, Departamento de Patología Clínica,

Facultad de Medicina Veterinaria y Zootecni

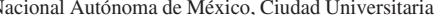

Av. Universidad 3000, Col. Copilco, México, D.F. 04150
Phones and Fax: (52) 562258 78, (52) 56225943 http://www.vfu.cz/acta-vet/actavethth 
Blood samples were centrifuged within $60 \mathrm{~min}$ after collection at $1000 \mathrm{~g}$, serum was immediately drawn off and refrigerated for analyses of enzyme activities or frozen for later analyses of other analytes. Serum urea, glucose, inorganic phosphorus concentrations and enzyme activities of aspartate aminotransferase (AST) and creatine kinase (CK) were measured by Microchem analyser 565 (Ciba-Corning). The enzyme assays were performed at $30{ }^{\circ} \mathrm{C}$. Serum concentrations of $\mathrm{Ca}^{2+}, \mathrm{Mg}^{2+}, \mathrm{Cu}$ and $\mathrm{Zn}$ were determined by atomic absorption spectrometry (Perkin-Elmer 3110). Serum levels of $\mathrm{Na}^{+}, \mathrm{K}^{+}$and $\mathrm{Cl}^{-}$were determined by the electrolyte analyser 644 (CibaCorning). The acid-base values: $\mathrm{pH}$, partial pressure of $\mathrm{CO}_{2}\left(\mathrm{pCO}_{2}\right)$, base excess $(\mathrm{BE})$, actual bicarbonate $\left(\mathrm{HCO}_{3}{ }^{-}\right.$ a), and total $\mathrm{CO}_{2}\left(\mathrm{TCO}_{2}\right)$ were determined by $\mathrm{pH} / \mathrm{blood}$ gas analyser 238 (Ciba-Corning) within $3 \mathrm{~h}$ after blood sampling.

Haemoglobin $(\mathrm{Hb})$ was measured spectrophotometrically using the cyanomethaemoglobin method, packed cell volume $(\mathrm{PCV})$ by microhaematocrit centrifuge and plasma protein by refractometer. Total leukocytes were counted using haemocytometer and differential counts were carried out on Wright's stained blood smears (Jain 1993).

Results were analysed by descriptive statistics and were expressed as mean, standard deviation (SD), minimum and maximum.

\section{Results}

Animals did not show any clinical signs of disease and their body condition was good. The mean values, standard deviations and ranges for blood biochemical, acid-base and haematological analytes are shown in Tables 1-2.

Table 1

Biochemical values in blood of red deer $(n=30)$

\begin{tabular}{|c|c|c|c|c|}
\hline Analyte & Mean & SD & $\min$ & $\max$ \\
\hline Urea $(\mathrm{mmol} / \mathrm{L})^{\mathrm{s}}$ & 6.32 & 1.45 & 4.85 & 8.11 \\
\hline Glucose $(\mathrm{mmol} / \mathrm{L})^{\mathrm{s}}$ & 5.09 & 1.36 & 2.80 & 8.42 \\
\hline $\operatorname{AST}(\mathrm{IU} / \mathrm{L})^{\mathrm{s}}$ & 54.3 & 15.9 & 36.0 & 123.0 \\
\hline $\mathrm{CK}(\mathrm{IU} / \mathrm{L})^{\mathrm{s}}$ & 221 & 103 & 79.0 & 409 \\
\hline $\mathrm{Na}^{+}(\mathrm{mmol} / \mathrm{L})^{\mathrm{S}}$ & 142.3 & 2.5 & 137.0 & 147.0 \\
\hline $\mathrm{K}^{+}(\mathrm{mmol} / \mathrm{L})^{\mathrm{s}}$ & 7.03 & 1.03 & 5.46 & 9.53 \\
\hline $\mathrm{Cl}^{-}(\mathrm{mmol} / \mathrm{L})^{\mathrm{s}}$ & 100.5 & 2.3 & 96.0 & 106.0 \\
\hline $\mathrm{Ca}^{2+}(\mathrm{mmol} / \mathrm{L})^{\mathrm{s}}$ & 2.12 & 0.26 & 1.90 & 2.55 \\
\hline $\mathrm{P}(\mathrm{mmol} / \mathrm{L})^{\mathrm{s}}$ & 2.41 & 0.32 & 2.03 & 2.90 \\
\hline $\mathrm{Mg}^{2+}(\mathrm{mmol} / \mathrm{L})^{\mathrm{s}}$ & 0.91 & 0.20 & 0.62 & 1.32 \\
\hline $\mathrm{Cu}(\mu \mathrm{mol} / \mathrm{L})^{\mathrm{s}}$ & 9.86 & 1.64 & 6.46 & 14.48 \\
\hline $\mathrm{Zn}(\mu \mathrm{mol} / \mathrm{L})^{\mathrm{s}}$ & 16.97 & 9.05 & 8.41 & 33.55 \\
\hline $\mathrm{pH}^{\mathrm{b}}$ & 7.41 & 0.04 & 7.30 & 7.51 \\
\hline $\mathrm{pCO}_{2}(\mathrm{~mm} \mathrm{Hg})^{\mathrm{b}}$ & 37.7 & 4.4 & 31 & 52 \\
\hline $\mathrm{HCO}_{3}{ }^{-} \mathrm{a}(\mathrm{mmol} / \mathrm{L})^{b}$ & 24.3 & 3.1 & 19.1 & 31.0 \\
\hline $\mathrm{BE}(\mathrm{mmol} / \mathrm{L})^{\mathrm{b}}$ & 0.73 & 3.22 & -5.7 & 8.10 \\
\hline $\mathrm{TCO}_{2}(\mathrm{mmol} / \mathrm{L})^{\mathrm{b}}$ & 25.3 & 3.2 & 20.8 & 31.7 \\
\hline
\end{tabular}

$\mathrm{SD}=$ standard deviation, $\mathrm{AST}=$ aspartate aminotransferase, $\mathrm{CK}=$ creatine kinase, $\mathrm{pCO}_{2}=$ partial pressure of carbon dioxide, $\mathrm{HCO}_{3}^{-} \mathrm{a}=$ actual bicarbonate, $\mathrm{BE}=$ base excess, $\mathrm{TCO}_{2}=$ total carbon dioxide, $\mathrm{s}=$ serum, $\mathrm{b}=\mathrm{blood}$

\section{Discussion}

Blood serum urea concentration $(6.32 \mathrm{mmol} / \mathrm{L})$ was lower in this study than that determined by Wilson and Pauli (1983) and Knox et al. (1988). This analyte reflects the intake of effective rumen-degradable protein and its balance with fermentable metabolizable energy. Increased levels of blood serum urea may be associated with an excess of dietary protein, with deficiency of energy in the ration, with augmented catabolism of the animal or with prerenal, renal and postrenal azotemia (Kelly et al. 1988; Seglar 1997, Meyer and Harvey 1998).

The mean serum glucose concentration determined by us was lower and less variable than that determined by Wils on and Pauli (1983) but it was three times higher than the value 
Table 2

Haematological values in red deer $(n=60)$

\begin{tabular}{|l|c|c|c|c|}
\hline Analyte & Mean & SD & $\min$ & $\max$ \\
\hline Haemoglobin (g/L) & 156 & 29.5 & 72 & 182 \\
\hline PCV (L/L) & 0.47 & 0.047 & 0.32 & 0.56 \\
\hline Plasma protein (g/L) & 66.0 & 6.6 & 50.0 & 80.0 \\
\hline Total WBC (x10\%/L) & 4.8 & 1.38 & 2.20 & 6.55 \\
\hline Neutrophils (\%) & 40.07 & 8.01 & 26 & 5 \\
\hline Bands (\%) & 0.44 & 1.15 & 0 & 63 \\
\hline Lymphocytes (\%) & 48.13 & 7.83 & 22 & 15 \\
\hline Monocytes (\%) & 5.31 & 2.70 & 0 & 11 \\
\hline Eosinophils (\%) & 2.94 & 2.57 & 0 & 9 \\
\hline Basophils (\%) & 3.12 & 2.28 & 0 & 5 \\
\hline
\end{tabular}

$\mathrm{SD}=$ Standard deviation, $\mathrm{PCV}=$ packed cell volume, $\mathrm{WBC}=$ white blood cell

described by Knox et al. (1988). The reference range values for plasma glucose $(0.18-3.32 \mathrm{mmol} / \mathrm{L})$ determined by Knox et al. (1988) are extremely low and markedly different from other domestic ruminants (Jagoš and B ouda 1981; Kaneko et al. 1997) and we have not determined such low concentration as $0.18 \mathrm{mmol} / \mathrm{L}$. The glucose level is related to a nutritional status, although some factors such as stress can contribute to its higher value (Wolfe et al. 1982).

The activities of AST in serum of red deer in our study were mildly higher than those determined by Wilson and Pauli (1983), but corresponded to the values described by Knox et al. (1988). Serum AST activities are elevated during muscle or liver damage in bovine and equine species, and their peak activities occur 24 - $48 \mathrm{~h}$ after injury (Meyer and Harvey 1998).

Serum CK activities determined by us were lower than those described by Wils on and Pauli (1983) and they were similar to activities stated by Knox et al. (1988), Reid and Towers (1985). Increased CK activities are usually associated with muscular dystrophy or exercise (Anderson 1976; Anderson et al. 1976).

Blood serum concentrations of $\mathrm{Na}^{+}$and $\mathrm{K}^{+}$(142.3 and $7.03 \mathrm{mmol} / \mathrm{L}$, respectively) were higher than those (138.4 and $4.67 \mathrm{mmol} / \mathrm{L}$, respectively) determined by Wils on and Pauli (1983), but they were lower than those described by Knox et al. (1988) (150 and 12.8 $\mathrm{mmol} / \mathrm{L}$, respectively). The average serum $\mathrm{K}^{+}$concentration in red deer determined by us and specially the reference value for $\mathrm{K}^{+}$described by Knox et al. (1988) is markedly higher in comparison with that in other domestic animals (Jagoš and Bouda 1981; Meyer and Harvey 1998; Kaneko et al. 1997). However, the average serum concentrations of $\mathrm{Na}^{+}$, $\mathrm{Cl}^{-}$and blood acid-base values were consistent with those in cattle and sheep (Jagoš and B ouda 1981). The variations in reference blood plasma concentrations, the ranges for $\mathrm{Na}^{+}$ (70-220 mmol/L) and $\mathrm{K}^{+}(2.1-21.4 \mathrm{mmol} / \mathrm{L})$ described by Knox et al. (1988) are markedly different from values determined by us and those in other domestic animals (Jagoš and Bouda 1981; Meyer and Harvey 1998; Kaneko et al. 1997). We have never found these extreme serum values for $\mathrm{Na}^{+}$and $\mathrm{K}^{+}$in domestic species. Average serum $\mathrm{Cl}^{-}$ concentration was lower than that described by Hargreaves and Matthews (1995). Serum electrolyte concentrations are important for the estimation of hydration in deer and according to Hargreaves and Matthews (1995) they are more useful than haemoconcentration as an hydration index in red deer.

The plasma concentrations of $\mathrm{Na}^{+}, \mathrm{K}^{+}, \mathrm{Cl}^{-}$and $\mathrm{TCO}_{2}$ are also important for the exact determination of acid-base disorders, especially mixed acid-base disorders ( $\mathrm{Russell}$ et al. 1996). The average serum concentrations of $\mathrm{Ca}^{2+}$, inorganic $\mathrm{P}$ and $\mathrm{Mg}^{2+}(2.12,2.41$ and 0.90 
$\mathrm{mmol} / \mathrm{L}$, respectively) were higher than those $(1.79,2.11$ and $0,75 \mathrm{mmol} / \mathrm{L}$, respectively) described by Wilson and Pauli (1983), but they were lower than those determined by Knox et al. (1988) (2.78, 2.83 and $1.04 \mathrm{mmol} / \mathrm{L}$, respectively). These differences can be explained by the composition of pasture, management and age of animals.

The average serum $\mathrm{Cu}$ concentrations were less variable in our study than those measured by Knox et al. (1988). Copper is an important serum trace element and its deficiency has been associated frequently with poor growth and hair colour changes (Fyffe 1996). The optimum plasma concentration of $\mathrm{Cu}$ is important for normal reproduction and performance (Suttle 1986; Gooneratne et al. 1989).

The average serum $\mathrm{Zn}$ concentration found by us was consistent with reference values described by Jag oš and B ouda (1981) in other ruminants, but the lower range value was below reference range values. Optimum serum $\mathrm{Zn}$ concentrations are needed for adequate immunity (Mills 1987).

Blood acid-base values determined in this study are the first reference in red deer and are consistent with the values described by Presidente et al. (1973) in White-tailed deer during immobilization with etorphine and xylazine and with values in bovine (Jagoš and Bouda 1981).

The values of PCV, haemoglobin and plasma protein in this study corresponded to values in unsedated farmed red deer (Cross et al. 1988; Hargreaves and Matthews 1995). The values of PCV and $\mathrm{Hb}$ in farmed red deer with xylazine sedation were lower than those in physically restrained animals (Cross et al. 1988). Wilson and Pauli (1982) concluded that samples collected from fully conscious deer are likely to produce higher concentrations of haemoglobin and values of PCV. According to Turner and Hodgetts (1959) the spleen of the red deer has a bilayered capsule with substantial amounts of smooth muscle, indicating that this has red cell storage as a major function. It seems probable that a major contribution to the observed changes is caused by the spleen contraction due to adrenaline, released during manual restraint of the animal.

The average WBC value in our study was consistent with that in red deer described by Upcott and Herbert (1965), but a higher value was determined by Wils on and Pauli (1982). Differential WBC counts varied markedly according to these authors. In our study the percentage of neutrophils was lower than that recorded by Wolfe et al. (1982), Wils on and Pauli (1982), whereas percentage of lymphocytes was higher. The values of other granulocytes and monocytes determined by us were similar to those described elsewhere on many deer species (Peterson and Pedersen 1975).

Biochemical and haematological values determined in red deer at the altitude above $2000 \mathrm{~m}$ are the first reference and can be used as indicators for control of health status and diagnosis of disease in farmed red deer.

\section{Biochemické a hematologické hodnoty ve venózní krvi jelenů Cervus elaphus ve vysoké nadmořské výšce}

Biochemické hodnoty byly stanoveny ve venózní krvi 30 a hematologické hodnoty u 60 jelenů, průměrné hmotnosti $53,9 \mathrm{~kg}$, věku 5 měsíců, chovaných na pastvě v centrálním Mexiku, v nadmořské výšce $2450 \mathrm{~m}$. V krevním séru klinicky zdravých zvířat bez použití sedace byly průměrné hodnoty koncentrace močoviny $6,32 \mathrm{mmol} / \mathrm{L}$, glukózy 5,09 mmol/L, $\mathrm{Na}^{+} 142 \mathrm{mmol} / \mathrm{L}, \mathrm{K}^{+} 7,03 \mathrm{mmol} / \mathrm{L}, \mathrm{Cl}^{-} 100,5 \mathrm{mmol} / \mathrm{L}, \mathrm{Ca}^{2+}$ 2,12 mmol/L, anorganického

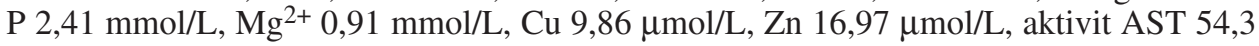
IU/L a kreatinkinasy $221 \mathrm{IU} / \mathrm{L}$. V krvi byly hodnoty $\mathrm{pH} 7,41, \mathrm{pCO}_{2} 37,7 \mathrm{~mm} \mathrm{Hg}$, aktuálního bikarbonátu 24,3 mmol/L, přebytku bází $0,73 \mathrm{mmol} / \mathrm{L}$, celkového $\mathrm{CO}_{2} 25,3 \mathrm{mmol} / \mathrm{L}$, hemoglobinu $156 \mathrm{~g} / \mathrm{L}$, hematokritu $0,47 \mathrm{~L} / \mathrm{L}$, leukocytů $4,8 \times 10^{9} / \mathrm{L}$ a celkových bílkovin v krevní plasmě 66,0 g/L. Biochemické a hematologické hodnoty stanovené v krvi jelenů 
v nadmořské výšce nad 2000 m jsou první referencí a zároveň mohou být využity v diagnostice a prevenci onemocnění těchto zvířat.

\section{Acknowledgements}

The authors express their gratitude to QFB. R. Salcedo and QBP. A. Castillo for biochemical analysis of blood samples.

\section{References}

ANDERSON, M. G. 1976: The effect of exercise on the lactic dehydrogenase and creatine kinase composition of horse serum. Res. Vet. Sci. 20: 191-196

ANDERSON, M. G., BERRETT, S., PATTERSON, D. J. 1976: The significance of elevated plasma creatine phosphokinase activity in muscle disease of cattle. J. Comp. Pathol. 86: 531-538

BOUDA, J., JAGOŠ, P. 1991: Disorders in the acid-base balance. In Vrzgula L.: Metabolic disorders and their prevention in farm animals. Elsevier, Amsterdam, pp. 248-268

CROSS, J. P., MACKINTOSH, C. G., GRIFFIN, J. F. 1988: Effect of physical restraint and xylazine sedation on haematological values in red deer (Cervus elaphus). Res. Vet. Sci. 45: 281-286

FYFFE, J. J. 1996: Serum Cu concentrations and clinical signs in red deer (Cervus elaphus) during drought in Central Victoria. Austral. Vet. J. 73: 188-191

GOONERATNE, S. R., BUCKLEY, W.T., CHRISTENSEN, D. A. 1989: Review of copper deficiency and metabolism in ruminants. Can. J. Anim. Sci. 69: 819-845

HARGREAVES, A. L., MATTHEWS, L. R. 1995: The effect of water deprivation and subsequent access to water on plasma electrolytes, haematocrit and behaviour in red deer. Livestock Prod. Sci. 42: 73-79

JAGOŠ, P., BOUDA, J. 1981: Základní biochemické a hematologické hodnoty u domácích zvířat a nové způsoby vyjadrování výsledků laboratorních vyšetření. SVS, Oddělení Veterinární Osvěty, Pardubice, 29 p. (In Czech)

JAIN, N. C. 1993: Examination of the blood and bone marrow. In Jain N. C.: Essentials of veterinary hematology. Lea \& Febiger, Philadelphia, pp. 2-5

KANEKO, J. J., HARVEY, J. W., BRUSS, M. L. 1997: Blood analyte reference values in large animals. In Kaneko, J. J., Harvey J. W. and Bruss M. L.: Clinical biochemistry of domestic animals. $5^{\text {th }}$ ed. Academic Press, San Diego, pp. 890-895

KELLY, S. M., WHITAKER, D. A., SMITH, E. S. 1988: A dairy herd health and productivity service. Br. Vet. J. 144: 470-481

KNOX, D. P., McKELVEY, W. C., JONES, D. G. 1988: Blood biochemical reference values for farmed red deer. Vet. Rec. : 109-112

MEYER, D. J., HARVEY, J. W. 1998: Veterinary Laboratory Medicine. WB Saunders, Philadelphia, pp 343-359

MILLS, C. F. 1987: Biochemical and physiological indicators of mineral status in animals: copper, cobalt and zinc. J. Anim. Sci. 65: 1702-1711

PETERSON, R. S., PEDERSEN, A. A. 1975: Blood chemistry and hematology of elk. J. Wildlife Management 39: $617-620$

PRESIDENTE, P. J., LUMSDEN, J.H., PRESNELL, K. R., RAPLEY, W.A., MCCRAW, B. M. 1973: Combination of etorphine and xylazine in captive white-tailed deer. II. Effects on hematologic, serum biochemical and blood gas values. J. Wildlife Management 37: 342-348

REID, T. C., TOWERS, N. R. 1985: Blood parameters of normal farmed deer. In Proceedings of an International Conference. Wellington, New Zealand, February 13-18, p 83-86

RUSSELL, K. E., HANSEN, B. D., STEVENS, J. B. 1996: Strong ion difference approach to acid-base imbalances with clinical application to dogs and cats. Vet. Clin. North Am. (Small Anim. Pract.) 26: 1185-1201

SEGLAR, W. S. 1997: Dairy production management-maximising forage quality. Compendium Cont. Educ. Vet. Pract. 19: 254-261

SUTTLE, N. F. 1986: Copper deficiency in ruminants; recent developments. Vet. Rec. 119: 519-522

TURNER, A.W., HODGETTS, V. E. 1959: The dynamic red cell storage function of the spleen in sheep. I. Relationship to fluctuations of jugular haematocrit. Austral. J. Exp. Biology Med. Sci. 37: 399-420

UPCOTT, D. H., HERBERT, C. N. 1965: Some haematological data for red deer (Cervus elaphus) in England. Vet. Rec. 77: 1348-1349

WILSON P. R., PAULI, J. V. 1982: Blood constituents of farmed red deer (Cervus elaphus): I. Haematological values. New Zealand Vet. J. 30: 174-176

WILSON, P. R., PAULI, J. V. 1983: Blood constituents of farmed red deer (Cervus elaphus): II. Biochemical values. New Zealand Vet. J. 31: 1-3

WOLFE, G., KOCAN, A. A., THEDFORD, T. R., BARRON, S. J. 1982: Hematologic and serum chemical values of adult female mountain elk from New Mexico and Oklahoma. J. Wildlife Dis. 18: 223-227 